\title{
Ground Pearls, Earth Pearls, Pearl Scale, Margarodes spp. (Insecta: Hemiptera: Margarodidae) ${ }^{1}$
}

Anthony Camerino ${ }^{2}$

\section{Introduction}

Ground pearls are a primitive subterrestrial relative of the widely recognized above ground armored scale insect (family Diaspididae). While retaining well-developed fossorial legs with numerous setae (which scale insects do not have), ground pearls do not possess the ability to secrete scales similar to their scale relatives (Beardsley and Gonzalez). Instead, the ground pearls excrete a waxy covering that totally surrounds their body with the exception of their piercing- sucking mouthparts. The voided waxy spherical covering of the insect is the most likely structure to be encountered. The sphere is pink to yellowish-brown in color and measures from $1 / 6$ of an inch in diameter to as small as a grain of sand (Short). The exposed mouthparts are used to feed and attach to the roots of plants.

\section{Distribution and Dispersal}

Reports of ground pearls as pests occur in Australia, the southwestern USA, and the southeastern USA (Allsopp et al., Buss, Hoffman and Smith). More than likely, the distribution is further-reaching than the ranges stated above, but

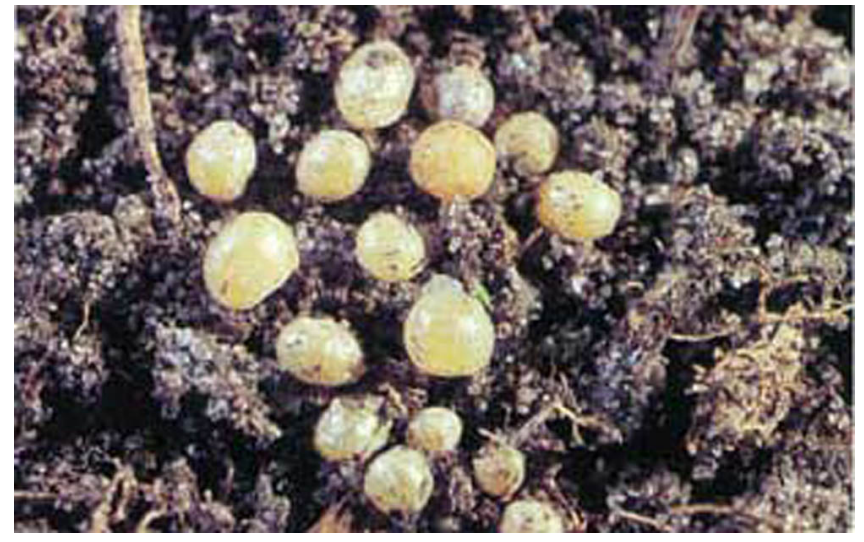

Figure 1. Immature ground pearls, Margarodes spp., in centipede grass. Credits: David Shetlar, Ohio State University

because of the low pest priority status of the insect distribution is under-studied. In Florida, ground pearl populations are believed to be restricted from the panhandle to North Central Florida (Alachua county) (Buss).

The Margarodes species' small size and below soil-surface habitat limit the ability of the insect to move very far by natural means. Ground pearls must dig through the soil in order to locate a new feeding site. Migration rates through continuous patches of turf have been calculated at a maximum rate of 4 to 6

1. This document is EENY-277, one of a series of Featured Creatures from the Entomology and Nematology Department, Florida Cooperative Extension Service, Institute of Food and Agricultural Sciences, University of Florida. Published: November 2002. This document is also available on Featured Creatures Website at http://creatures.ifas.ufl.edu. Please visit the EDIS Website at http://edis.ifas.ufl.edu.

2. Anthony Camerino, Entomology and Nematology Department, University of Florida, Gainesville, FL.

The Institute of Food and Agricultural Sciences (IFAS) is an Equal Employment Opportunity - Affirmative Action Employer authorized to provide research, educational information and other services only to individuals and institutions that function without regard to race, creed, color, religion, age, disability, sex, sexual orientation, marital status, national origin, political opinions or affiliations. For information on obtaining other extension publications, contact your county Cooperative Extension Service office. Florida Cooperative Extension Service / Institute of Food and Agricultural Sciences / University of Florida / Larry R. Arrington, Interim Dean 
inches per year (Hoffman and Smith). The expansion of a ground pearl population occurs in an irregular circular shape.

As a result of Margarodes species' extremely slow dispersal rate, long distance movement of the organism is attributed to anthropogenic causes. Examples of human induced ground pearl introduction into uninfected sites include movement of infested organic material on tools, farming implements and tractors, or sale and/or introduction of infested plants are all examples of possible vectors.

\section{Life Cycle}

During late spring/early summer adult female ground pearls, which are pink in color, emerge from their pearl cysts, migrate, and then lay up to 100 eggs into a chamber consisting of a wax- like filament. During favorable conditions, a female may have several egg laying episodes in a single year. The eggs hatch several days after being laid. The first instars (called crawlers) leave their encasement and seek out a healthy root on which to feed. Once established the nymphs begin to secrete their outer covering and develop into "ground pearls." During the summer and into the fall the nymphs continue to develop. By late fall/winter the insects are adults and overwinter in the cyst/pearl surrounding them. The life cycle appears to be predominately parthenogenic (Hoffman and Smith).

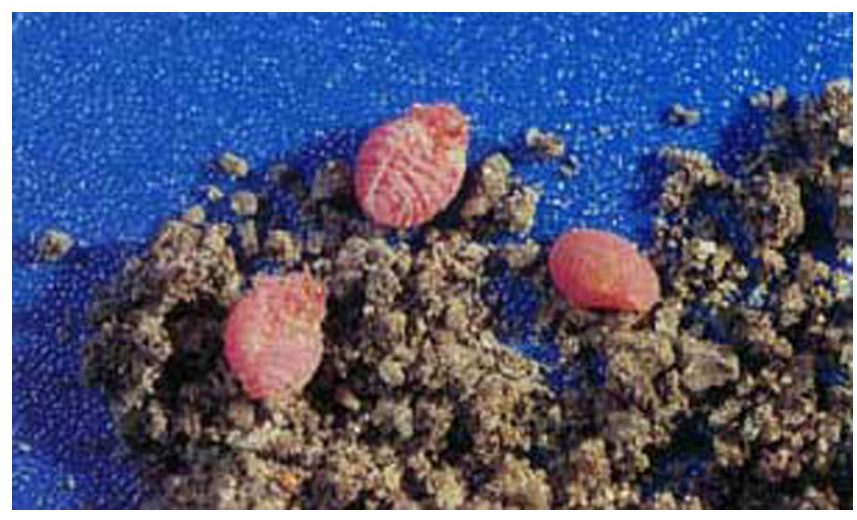

Figure 2. Mature female ground scales, Margarodes spp., found in soil sample. Credits: David Shetlar, Ohio State University

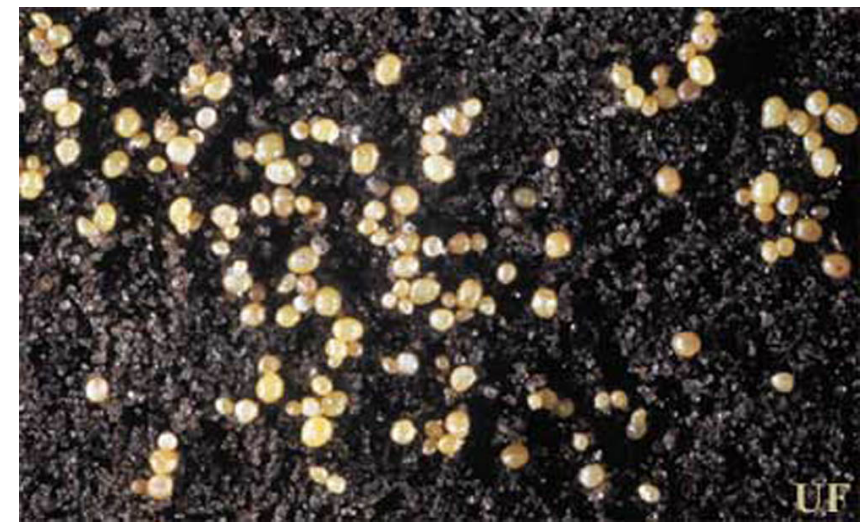

Figure 3. Various life stages of ground pearls, Margarodes spp. Credits: University of Florida

\section{Economic Importance}

Ground pearls are chiefly restricted to grasses. Centipedegrass is highly prone to ground pearl attacks, but St. Augustinegrass, bermudagrass, and zoysiagrass can also be infested (Buss, Hoffman and Smith, Short). Reports from Australia name sugarcane as a potential host (Allsopp et al.). In addition, grape roots have also been reported to incur damage from ground pearl species in California (Barnes et al.). Exact impact, measured in dollars, is unavailable for sugarcane and grapes. In turf, the acceptable damage level will largely depend on an individual's preference and the utility of the turf (e.g., athletic professional turf versus public playing fields). Turf damage is characterized by yellowing of the grass followed by browning and death along with the presence of the insect. If a plant is experiencing stressful conditions (e.g., over-watering, very low mowing heights, etc.) large expanding brown/dead patches of grass may appear (Short).

\section{Management}

No insecticides are recommended for control of ground pearls. The insect's ability to avoid insecticides is believed to be the result of the insects' long encysted/pearl stage and depth in soil (up to 12 in.) (Hoffman and Smith). Proper mowing height, fertilization, and watering will help prevent ground pearl infestations in turf (Short). Since the organism moves slowly and resides only as deep as the root zone, manual removal of infested areas with a generous buffer zone may alleviate the problem, but this remains to be verified. In agricultural situations, fallow periods with regular tillage or crop rotation 
with a non-grass crop may reduce population levels.

The life cycle of some species of ground pearls is two or more years (Allsopp et al.). The multiyear life span should be taken into account when planning pest control strategies. All equipment used in affected areas should be properly cleaned before leaving a ground pearl-infested area.

\section{Selected References}

Allsopp PG, McGill NG, Stringer JK. (2000). Host-plant resistance in sugarcane to pink ground pearls, Eumargarodes laingi Jakubski (Hemiptera: Margarodidae): Confirmation and further screening of clones. Australian Journal of Entomology. 39:316-321.

Barnes MM, Ash CR, Deal AS. (1954). Ground pearls on grape roots. California Agriculture. 8: 5.

Beardsley JW, Gonzalez RH. (1975). The biology and ecology of armored scales. Annual Review of Entomology. 20: 47-73.

Buss EA. (2001). Insect Pest Management on Turfgrass. EDIS. http://edis.ifas.ufl.edu/IG001 (20 Jul. 2002).

Hoffman E, Smith RL. (1991). Emergence and dispersal of Margarodes meridionalis (Homoptera: Coccoidea) in hybrid bermudagrass. Journal of Economic Entomology. 84:1668- 1671.

Sorensen K. Arthropod pests of turf. Insect Principles: Identification and Management. http://www.cals.ncsu.edu/course/ent791r/handout/ turf/pearls.html (23 Jul. 2002).

Short DE. (1999). Ground pearls in lawns. EDIS. http://edis.ifas.ufl.edu/LH073 (20 Jul. 2002). 